\title{
COVID-19 and heme oxygenase: novel insight into the disease and potential therapies
}

\author{
Philip L. Hooper ${ }^{1}$ (ID
}

Received: 14 May 2020 / Revised: 22 May 2020 / Accepted: 25 May 2020 / Published online: 4 June 2020

(C) Cell Stress Society International 2020

\begin{abstract}
The COVID-19 pandemic needs therapies that are presently available and safe. We propose that subjects with metabolic syndrome, old age, and male gender have the greatest morbidity and mortality and have low stress proteins, in particular, low intracellular heme oxygenase (HO-1), making them particularly vulnerable to the disease. Additionally, COVID-19's heme reduction may contribute to even lower HO-1. Low-grade inflammation associated with these risk factors contributes to triggering a cytokine storm that spreads to multi-organ failure and near death. The high mortality of those treated with ventilator assistance may partially be explained by ventilator-induced inflammation. The cytoprotective and anti-inflammatory properties of HO-1 can limit the infection's damage. A paradox of COVID-19 hospital admissions data suggests that fewer cigarettesmokers are admitted compared with non-smokers in the general population. This unexpected observation may result from smoke induction of HO-1. Therapies with anti-viral properties that raise HO-1 include certain anesthetics (sevoflurane or isoflurane), hemin, estrogen, statins, curcumin, resveratrol, and melatonin. Controlled trials of these HO-1 inducers should be done in order to prevent or treat COVID-19 disease.
\end{abstract}

Keywords Heme oxygenase · COVID-19 · Therapy · Heat shock proteins · Ventilator · Inflammation · Cytokine storm . Smoking $\cdot$ Estrogen $\cdot$ Anesthesia $\cdot$ Elderly

The pandemic of COVID-19 virus caught the world unprepared. The reported deaths by the virus in the USA are now almost two times the number of US servicemen that died in the Viet Nam conflict—over 90,000 dead. This tragedy occurred in just three months. Effective treatment is not immediately evident. We propose stress proteins and in particular heme oxygenase 1 (HO-1, Hsp32) may play a role in the virus' pathological impact and as a therapeutic modality.

Conditions associated with a higher morbidity and mortality from COVID-19 infection are characteristics of the metabolic syndrome (insulin resistance, diabetes, obesity, hypertension, cardiovascular disease), old age, male gender, and mechanical ventilator support. Pertinently, these groups generally have lower intracellular stress protein levels including low HO-1. Low intracellular stress proteins make these

Philip L. Hooper

phoopermd@gmail.com

1 Division of Endocrinology and Metabolism, Department of Medicine, University of Colorado Anschutz Medical Campus, Aurora, CO, USA populations vulnerable to stress from whatever type of assault, whether infection, trauma, or poison (De Maio and Hightower 2020) (Hooper and Hooper 2005). Individuals with metabolic syndrome and insulin resistance have low-grade inflammation that can set a milieu for COVID-19 infection to trigger a cytokine storm, a common near-terminal event with multiorgan damage seen in COVID infection. (Mehta et al. 2020) Indeed, knocking out HO-1 genes in animal models increases lung damage caused by sepsis. (Chen et al. 2018) Conversely, raising HO- 1 and other stress reduces inflammation and improves insulin resistance and in animal models lengthens life span. (Hooper et al. 2014)

A peculiarity of COVID-19 infection may be blockade of heme production. (Wenzhong and Li 2020) The cytoprotective properties of HO-1 are largely the result of HO-1 enzymatic cleaving of heme into biliverdin, ferrous iron, and carbon monoxide. These products limit inflammation and oxidative stress, protecting tissues. (Fujioka et al. 2017; Takeda et al. 2017) COVID-19 blockade of heme synthesis could limit the HO-1 stress tolerance function, contributing to host fragility. Notably, in the Han Chinese population in Taiwan, protection from SARS corona viral infection is 
associated with a higher HO-1 expression in the HO$1(-497 \mathrm{~A} / *)$ genotype. (Hsieh et al. 2010)

Older individuals are at particular risk of dying from COVID-19. Recent data on 5700 hospitalized COVID-19 patients in New York City observed that the mortality of patients on mechanical ventilation over age 65 was $97.2 \%$, compared with $76.4 \%$ for those $18-65$. (Richardson et al. 2020) In an attempt to understand age-related COVID-19 mortality, Abouhashem and coworkers studied antioxidant genes including regulators of HO-1 in human alveolar tissue. They found a pronounced reduction of HO-1-inducing genes in tissue from older individuals relative to young. The authors proposed that the low HO-1 state in the older subjects might contribute to susceptibility to a hyper-inflammatory state that results in cytokine storm. (Abouhashem et al. 2020) Previous studies in rodents reported a reduced HO-1 response to heat- or alcoholinduced stress as animals aged. (Bloomer et al. 2009; Patriarca et al. 2007)

HO-1 has anti-viral activity. In animal studies, HO-1 induction by cobalt protoporphyrin or overexpression of its upstream regulatory gene, $\mathrm{Nrf} 2$, is effective in combating Hepatitis $\mathrm{C}$ and $B$ viruses, Ebola virus, human immunodeficiency virus, dengue virus, Zika virus, and human respiratory syncytial virus. (El Kalamouni et al. 2019; Espinoza et al. 2017) It is not surprising that some of these viruses turn off the production of HO-1, consistent with the stress protein being a threat to the virus, or that the host, in an attempt to resist viral commandeering of its protein synthesis, shuts down protein production, including stress proteins. (Hooper et al. 2012) Gene overexpression and cobalt protoporphyrin are not presently available clinically. However, hemin, a substrate for HO-1 obtained from the breakdown of red blood cells, is FDA approved for treatment of porphyria and is effective in blocking Zika viral replication. (Huang et al. 2017) To our knowledge, hemin has not been used to treat COVID-19.

The high mortality associated with mechanical ventilation in older COVID-19 patients prompts asking "does ventilation itself contribute to injury and poor outcomes?" One of the lessons learned from the New York City experience was to withhold intubation for as long as possible. Indeed, ventilator lung injury is well known in the anesthesia surgical fields. Specifically, cytokine activation and generation of reactive oxygen species contribute to a vicious cycle (Fig. 1) that can end in systemic inflammation and multi-organ failure. (Belperio et al. 2006)

Two volatile anesthetics (isoflurane and sevoflurane) raise heme oxygenase and aid in cytoprotection during heart and liver surgery. (Brioni et al. 2017; Schmidt 2004) Interestingly, long-term isoflurane helps recovery and reduces bronchospasm from herpes simplex pneumonia. (Hornuss et al. 2010) Sevoflurane improved pulmonary mechanics and gas exchange in a case series of infants with severe bronchiolitis and acute respiratory distress syndrome. (Nacoti et al. 2018) In short, a controlled clinical trial of isoflurane or sevoflurane when intubated COVID-19 patients are sedated is warranted.

Reports across the world repeatedly observe that sickest patients are male. Data from New York City found that among hospitalized COVID-19 patients under age 60, the death rate of women was one-third that of men. Among those over 60, the death rate of women was two-thirds that of men. (Richardson et al. 2020) Why the gender difference? Studies suggest that double $\mathrm{X}$ chromosomes allow females to carry twice the TLR7 gene than carried in males. TLR7 expressed in immune cells recognizes single-strand RNA viruses and
Fig. 1 Cytokine, endotoxin, and microbial agents released from the acute lung injury/acute respiratory distress syndrome (ALI/ ARDS) lung during injurious mechanical ventilation. Mechanical ventilationassociated and mechanical ventilation-induced lung injury causes impairment of the integrity of the alveolar-capillary membrane and results in augmented cytokine release leading to translocation of cytokines/endotoxin/microbial agents from the lung to the circulation, contributing to systemic inflammation and a multi-organ dysfunction syndrome. With permission (Belperio et al. 2006)

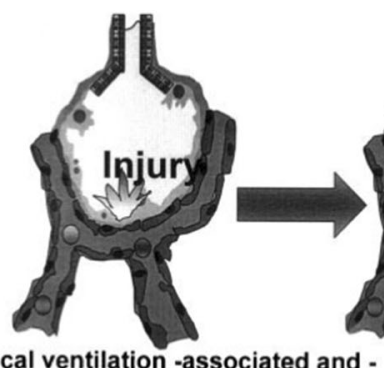

Mechanical ventilation -associated and Type I induced lung injury

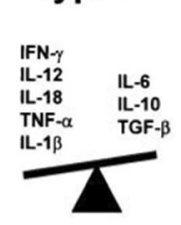

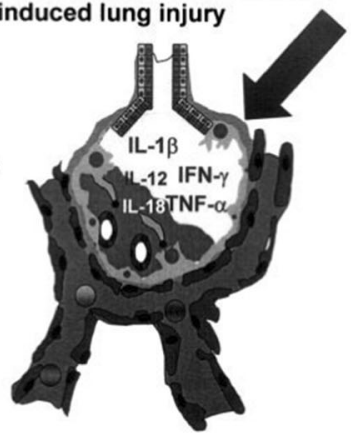

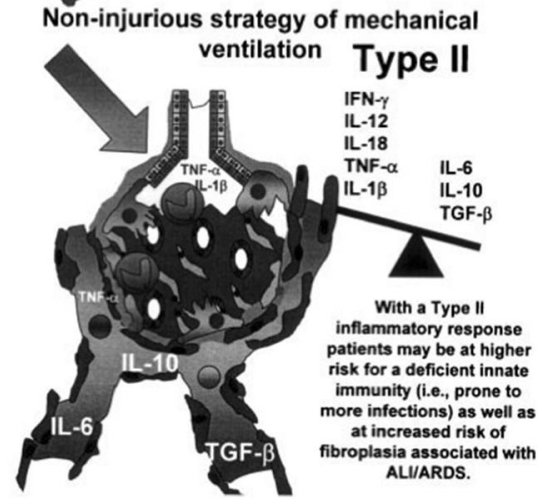


promotes production of antibodies against the virus, resulting in double protection for women. (Laffont et al. 2020) In addition to the double $\mathrm{X}$ hypothesis, hormonal differences between the genders may have a role in protecting females. Women have more stress proteins in their heart and less cardiovascular disease than men. (Knowlton and Korzick 2014) Estrogen administration reduces heart failure in postmenopausal women with failing hearts. (Lindenfeld et al. 2003) Relevantly, estradiol administration raised intracellular HO-1 and reduced inflammation, edema, and cell death in a rodent model of trauma-hemorrhage-induced lung injury. A specific HO-1 enzyme inhibitor blocked protective effects of estrogen against injury to the lung. (Hsu et al. 2013) It is no surprise that in the past month a Hungarian researcher, Zsuzsanna Suba, recommended that exogenous estrogen administration be given to COVID-19 victims, male or female. (Suba 2020) In our own experience, estrogen administration was effective in a hypotensive woman with staphylococcal toxic shock. She was not recovering after a week of conventional therapy until she received an injection of estradiol. (Hooper 1989)

A recent observation is that the prevalence of people who currently smoke cigarettes admitted for COVID-19 was low compared with the prevalence of smoking in the local general population. In China, current smokers had 1/4th the prevalence of COVID-19 hospitalizations as the general population smoking prevalence. In France, the smoker rate was 5\% of COVID-19 admissions compared with a 25\% smoker rate for the general French population. (Geier and Geier 2020) Relevantly and importantly, cigarette smoke is associated with increased HO-1 induction in lung fibroblasts and vascular endothelial cells. (Baglole et al. 2008; Yang et al. 2015)

Therapeutic medications and herbs that raise HO-1 have anti-viral activity and are readily available. These include HMG CoA reductase inhibitors (statins) (Fedson et al. 2015; Lee et al. 2004 melatonin (Anderson and Reiter 2020; Shi et al. 2019), curcumin (Aggarwal et al. 2013; Moghadamtousi et al. 2014), and resveratrol (El-hawary et al. 2019). Resveratrol is a stilbene, and pterostilbene is better absorbed than resveratrol. Thus, pterostilbene is the preferred stilbene (Kapetanovic et al. 2011). These agents have a good safety profile and are inexpensive. Additionally, a recently proposed hypothesis is to use hyperbaric oxygen therapy (HBOT) to improve oxygenation in COVID-19 patients. (De Maio and Hightower 2020) HBOT raises HO-1 levels and is cytoprotective. (Godman et al. 2010)

The ongoing pandemic may be slowed by therapies that are widely available. Appropriate trials should be done to find preventive and/or therapeutic products for COVID-19 infection.

\section{References}

Abouhashem AS, Singh K, Azzazy HM, Sen CK (2020) Is low alveolar type II cell SOD3 in the lungs of elderly linked to the observed severity of COVID-19? Antioxid Redox Signal:1-16. https://doi. org/10.1089/ars.2020.8111

Aggarwal BB, Gupta SC, Sung B (2013) Curcumin: an orally bioavailable blocker of TNF and other pro-inflammatory biomarkers. https:// doi.org/10.1111/bph.12131

Anderson G, Reiter RJ (2020) Melatonin: roles in influenza, Covid-19, and other viral infections. Rev Med Virol:e2109. https://doi.org/10. 1002/rmv.2109

Baglole CJ, Sime PJ, Phipps RP (2008) Cigarette smoke-induced expression of heme oxygenase- 1 in human lung fibroblasts is regulated by intracellular glutathione. Am J Physiol Lung Cell Mol Physiol 295(4):2006-2007. https://doi.org/10.1152/ajplung.90215.2008

Belperio JA, Keane MP, Lynch JP, Strieter RM, Ali THE, Lung A (2006) The role of cytokines during the pathogenesis of ventilatorassociated and ventilator-induced. Lung Injury 1(212):350-364. https://doi.org/10.1055/s-2006-948289

Bloomer SA, Zhang HJ, Brown KE, Kregel KC (2009) Differential regulation of hepatic heme oxygenase- 1 protein with aging and heat stress. J Gerontol A Biol Sci Med Sci 64(4):419-425. https://doi. org/10.1093/gerona/gln056

Brioni JD, Varughese S, Ahmed R, Bein B (2017) A clinical review of inhalation anesthesia with sevoflurane: from early research to emerging topics. J Anesth 31(5):764-778). Springer Tokyo. https://doi.org/10.1007/s00540-017-2375-6

Chen X, Wang Y, Xie X, Chen H, Zhu Q, Ge Z, Wei H, Deng J, Xia Z, Lian Q (2018) Heme oxygenase-1 reduces sepsis-induced endoplasmic reticulum stress and acute. Lung Injury. https://doi.org/10.1155/ 2018/9413876

De Maio A, Hightower LE (2020) COVID-19, acute respiratory distress syndrome (ARDS), and hyperbaric oxygen therapy (HBOT): what is the link? Cell Stress Chaperones:1-4. https://doi.org/10.1007/ s12192-020-01121-0

El Kalamouni C, Frumence E, Bos S, Turpin J, Nativel B, Harrabi W, Wilkinson DA, Meilhac O, Gadea G, Desprès P, Krejbich-Trotot P, Viranaïcken W (2019) Subversion of the heme oxygenase-1 antiviral activity by zika virus. Viruses 11(1). https://doi.org/10.3390/ v11010002

El-hawary SS, Ali ZY, Younis IY (2019) Hepatoprotective potential of standardized Ficus species in intrahepatic cholestasis rat model: involvement of nuclear factor- $\mathrm{kB}$, and Farnesoid $\mathrm{X}$ receptor signaling pathways. J Ethnopharmacol 231:262-274. https://doi.org/10.1016/ j.jep.2018.11.026

Espinoza JA, León MA, Céspedes PF, Gómez RS, Canedo-Marroquín G, Riquelme SA, Salazar-Echegarai FJ, Blancou P, Simon T, Anegon I, Lay MK, González PA, Riedel CA, Bueno SM, Kalergis AM (2017) Heme oxygenase-1 modulates human respiratory syncytial virus replication and lung pathogenesis during infection. $J$ Immunol 199(1):212-223. https://doi.org/10.4049/jimmunol.1601414

Fedson DS, Jacobson JR, Rordam M, Opal M (2015) Treating the host response to ebola virus disease with generic statins and angiotensin receptor blockers. mBIO 6(3):1-4. https://doi.org/10.1128/mBio. 00716-15

Fujioka K, Kalish F, Zhao H, Lu S, Wong S, Wong RJ, Stevenson DK (2017) Induction of heme oxygenase-1 attenuates the severity of sepsis in a non-surgical preterm mouse model. Shock. 47:242-250. https://doi.org/10.1097/SHK.0000000000000689

Geier MR, Geier DA (2020) Since January 2020 Elsevier has created a COVID-19 resource centre with free information in English and Mandarin on the novel coronavirus COVID- 19. The COVID-19 resource centre is hosted on Elsevier Connect, the company' $\mathrm{s}$ public news and information. January

Godman CA, Chheda KP, Hightower LE, Perdrizet G, Shin DG, Giardina C (2010) Hyperbaric oxygen induces a cytoprotective and angiogenic response in human microvascular endothelial cells. Cell Stress Chaperones 15(4):431-442. https://doi.org/10.1007/s12192-0090159-0 
Hooper PL (1989) Toxic shock syndrome and estrogen therapy. Ann Intern Med 111(3):263-264. https://doi.org/10.7326/0003-4819$111-3-263 \quad 2$

Hooper PL, Hooper JJ (2005) Loss of defense against stress: diabetes and heat shock proteins. Diabetes Technol Ther 7:204-208. https://doi. org/10.1089/dia.2005.7.204

Hooper PL, Hightower LE, Hooper PL (2012) Loss of stress response as a consequence of viral infection: implications for disease and therapy. Cell Stress Chaperones 17:647-655. https://doi.org/10.1007/ s12192-012-0352-4

Hooper PL, Balogh G, Rivas E, Kavanagh K, Vigh L (2014) The importance of the cellular stress response in the pathogenesis and treatment of type 2 diabetes. Cell Stress Chaperones 19(4):447-464. Cell Stress and Chaperones. https://doi.org/10.1007/s12192-014-0493-8

Hornuss C, Firsching M, Dolch M, Martignoni A, Peraud A, Briegel J (2010) Long-term isoflurane therapy for refractory bronchospasm associated with herpes simplex pneumonia in a heart transplant patient. Case Rep Med. https://doi.org/10.1155/2010/746263

Hsieh Y, Chen CWS, Schmitz SH, King C, Chen W, Wu Y, Ho M (2010). Candidate genes associated with susceptibility for SARScoronavirus. 122-132. https://doi.org/10.1007/s11538-009-9440-8

Huang H, Falgout B, Takeda K, Yamada KM, Dhawan S (2017) Nrf2dependent induction of innate host defense via heme oxygenase-1 inhibits Zika virus replication. Virology 503:1-5. https://doi.org/10. 1016/j.virol.2016.12.019

Kapetanovic IM, Muzzio M, Huang Z, Thompson TN, McCormick DL (2011) Pharmacokinetics, oral bioavailability, and metabolic profile of resveratrol and its dimethylether analog, pterostilbene, in rats. Cancer Chemother Pharmacol 68:593-601. https://doi.org/10. 1007/s00280-010-1525-4

Knowlton AA, Korzick DH (2014) Estrogen and the female heart. Mol Cell Endocrinol 389:31-39. https://doi.org/10.1016/j.mce.2014.01.002

Laffont S, Rouquié N, Azar P, Seillet C, Plumas J, Aspord C, Guéry J (2020) from women. https://doi.org/10.4049/jimmunol.1303400

Lee T, Chang C, Zhu Y (2004) Simvastatin induces heme oxygenase-1 a novel mechanism of vessel protection. Circulation 110:1296-1302. https://doi.org/10.1161/01.CIR.0000140694.67251.9C

Lindenfeld JA, Ghali JK, Krause-Steinrauf HJ, Khan S, Adams K, Goldman S, Peberdy MA, Yancy C, Thaneemit-Chen S, Larsen RL, Young J, Lowes B, Rosenberg YD (2003) Hormone replacement therapy is associated with improved survival in women with advanced heart failure. J Am Coll Cardiol 42(7):1238-1245. https:// doi.org/10.1016/S0735-1097(03)00938-0

Mehta P, Mcauley DF, Brown M, Sanchez E, Tattersall RS, Manson JJ, Across HLH, Collaboration, S (2020) COVID-19: consider cytokine storm syndromes and immunosuppression. Lancet 395(10229):1033-1034. https://doi.org/10.1016/S0140-6736(20) 30628-0
Moghadamtousi S, Abdul Kadir H, Hassandarvish P, Tajik H, Abubakar S, Zandi K (2014) A review on antibacterial, antiviral, and antifungal activity of curcumin. Biomed Res Int. https://doi.org/10.1155/ 2014/186864

Nacoti M, Colombo J, Fochi O, Bonacina D, Fazzi F, Bellani G, Bonanomi E (2018) Sevoflurane improves respiratory mechanics and gas exchange in a case series of infants with severe bronchiolitis-induced acute respiratory distress syndrome. https:// doi.org/10.1002/ccr3.1490

Patriarca S, Furfaro AL, Cosso L, Pesce Maineri E, Balbis E, Domenicotti C, Nitti M, Cottalasso D, Marinari UM, Pronzato MA, Traverso N (2007) Heme oxygenase 1 expression in rat liver during ageing and ethanol intoxication. Biogerontology 8(3):365-372. https://doi.org/ 10.1007/s10522-006-9079-x

Richardson S, Hirsch JS, Narasimhan M et al (2020) Presenting characteristics, comorbidities, and outcomes among 5700 patients hospitalized with COVID-19 in the New York City Area. JAMA. Network. https://doi.org/10.1001/jama.2020.6775

Schmidt R (2004) Cobalt protoporphyrin as a potential therapeutic agent? 79106. https://doi.org/10.1096/fj.07-0904ltr

Shi S, Lei S, Tang C, Wang K, Xia Z (2019) Melatonin attenuates acute kidney ischemia / reperfusion injury in diabetic rats by activation of the SIRT1 / Nrf2 / HO-1 signaling pathway. 0 (January): $1-13$

Suba Z (2020) Prevention and therapy of COVID-19 via exogenous estrogen treatment for both male and female patients; an opinion paper. $75-85$

Takeda TA, Sasai M, Adachi Y, Ohnishi K, Fujisawa JI, Izawa S, Taketani S (2017) Potential role of heme metabolism in the inducible expression of heme oxygenase-1. Biochim Biophys Acta Gen Subj 1861(7):1813-1824. https://doi.org/10.1016/j.bbagen.2017. 03.018

Te Hsu J, Yeh HC, Chen TH, Kuo CJ, Lin CJ, Chiang KC, Yeh TS, Hwang TL, Chaudry II (2013) Role of Akt/HO-1 pathway in estrogen-mediated attenuation of trauma-hemorrhage-induced lung injury. J Surg Res 182(2):319-325. https://doi.org/10.1016/j.jss. 2012.10.926

Wenzhong L, Li H (2020) COVID-19: attacks the 1-beta chain of hemoglobin and captures the porphyrin to inhibit human heme metabolism. 1. https://doi.org/10.26434/chemrxiv.11938173.v8

Yang G, Li Y, Wu W, Liu B, Ni L, Wang Z, Miao S, Wang L, Liu C (2015) Anti-oxidant effect of heme oxygenase-1 on cigarette smokeinduced vascular injury. Mol Med Rep 12(2):2481-2486. https:// doi.org/10.3892/mmr.2015.3722

Publisher's note Springer Nature remains neutral with regard to jurisdictional claims in published maps and institutional affiliations. 